\title{
INTERESY PAWLIKOWSKICH W STARZAWIE W LATACH 20. I 30. XX W. MAJĄTEK NOWOSTAWY
}

\author{
Abstract \\ The PaWlikowski family's businesSes in StaRzaWa IN THE 1920S and 1930s. \\ THE NOWOSTAWY ESTATE
}

This paper shows the circumstances of the Rozwadowski family's arrival in the Przemyśl Region and establishing the famous fish farm in Starzawa. The article also contributes to the history of the Pawlikowskis from Medyka. In the late 1920s Michał Pawlikowski got Wincenty Rozwadowski (owner of Babin near Kalush /Kałusz/) interested in setting up fish ponds in Starzawa near Mostyska (Mościska), property of his father Jan Gwalbert Pawlikowski, of which he was administrator. Following long negotiations, in 1931 J.G. Pawlikowski sold to Wincenty Rozwadowski and his children 414 hectares of land in Starzawa, including marshy meadowland and wasteland. The Rozwadowskis established there a new structure called Starzawa Stawy (Starzawa Ponds), soon renamed Nowostawy, and W. Rozwadowski established a large fish farm there. In the 1930s the estate was administered by Wincenty's son, Bartłomiej Rozwadowski, who got arrested by NKVD in October 1939 and all trace of him was lost. After the war the ponds were nationalized and the former owners were hardly ever mentioned again.

Keywords: Michal Pawlikowski, Jan Gwalbert Pawlikowski, Wincenty Rozwadowski, Bartłomiej Rozwadowski, the Pawlikowski family, the Rozwadowski family, Medyka, Starzawa, Nowostawy, fish ponds

Słowa kluczowe: Michał Pawlikowski, Jan Gwalbert Pawlikowski, Wincenty Rozwadowski, Bartłomiej Rozwadowski, Pawlikowscy, Rozwadowscy, Medyka, Starzawa, Nowostawy, stawy rybne

Przez lata narosło wiele mitów związanych z powstaniem w okresie międzywojennym XX w. gospodarstwa rybnego w Starzawie (dawne Nowostawy, obecnie Starzawa Rybna w gminie Stubno). W skąpej literaturze tematu, głównie w biogramach i przewodnikach turystyczno-krajoznawczych, pojawiają się też różne daty jego założenia ${ }^{1}$. Trudno się temu dziwić, skoro problematyka ta nie doczekała się dotąd rzetelnego historycznego opracowania. Wydarzenia wojenne zmusiły rodzinę Rozwadowskich

${ }^{1}$ T. Epsztein, S. Górzyński, Ziemianie polscy XX w. Słownik biograficzny, cz. 10, Warszawa 2013, s. 103; T. Misiak, $W$ dorzeczu środkowego Sanu. Środowisko przyrodnicze. Przemiany na przestrzeni wieków i ochrona, Przemyśl 2005, s. 111; G. Rąkowski, Polska Egzotyczna, cz. II, Pruszków 2002, s. 388; Szlaki znane i nieznane na obszarze działania Lokalnej Grupy Rybackiej ,,Starzawa”, Rzeszów 2013, s. 4-5; J. Różański, Przemyśl i okolice, Warszawa 1972; J. Woś, Odłowy, „Widnokrąg” 1984, nr 6, s. 1-2. 
- założycieli Nowostawów - do opuszczenia ziemi przemyskiej, a po znacjonalizowaniu majątku o dawnych właścicielach nie mówiło się prawie wcale. Mało kto łączy też tamte strony z rodziną Pawlikowskich z Medyki, dawnych właścicieli Starzawy (gros ich majątku ziemskiego pozostał po ukraińskiej stronie granicy). Dlatego celem niniejszego artykułu jest przybliżenie czytelnikom okoliczności związanych z przybyciem do ziemi przemyskiej rodziny Rozwadowskich i powstania słynnego gospodarstwa rybnego. Jednocześnie artykuł jest kolejnym przyczynkiem do wypełnienia brakujących kart w historiografii dotyczącej rodziny Pawlikowskich z Medyki, a zarazem uzupełnieniem artykułu opublikowanego w t. 54 „Rocznika Przemyskiego" pt. Michat Pawlikowski jako ziemianin - właściciel klucza medyckiego w latach 1919-19392.

W 1809 r. Józef Benedykt Pawlikowski nabył od księżnej Anny z Cetnerów Lotaryńskiej majątek ziemski w Starzawie koło Mościsk za 400000 florenów3. Od tamtej pory aż do wybuchu II wojny światowej własność ta pozostawała w rękach kolejnych przedstawicieli rodziny Pawlikowskich, stanowiąc istotną część majątku rodzinnego, obejmującego również Medykę z przyległościami oraz Kniażyce. W 1905 r. dobra te przeszły drogą dziedziczenia w ręce Jana Gwalberta Pawlikowskiego, doktora prawa, profesora Szkoły Rolniczej w Dublanach, badacza mistyki Juliusza Słowackiego i pioniera ochrony przyrody w Polsce ${ }^{4}$. Pod jego bezpośrednią administracją majątek pozostawał do wybuchu I wojny światowej. We wrześniu 1919 r. Jan Gwalbert podzielił własność pomiędzy siebie i synów. Pierworodnemu Michałowi ${ }^{5}$ oddał klucz medycki i ogólny nadzór nad dobrami rodzinnymi, młodszemu Janowi ${ }^{6}$ - klucz południowy z Kniażycami, Kormanicami i Witoszyńcami, dla siebie zaś pozostawił Starzawę z Baczmahą (ok. 1700 ha) ${ }^{7}$, którą wkrótce oddał w dzierżawę zięciowi Henrykowi Woźniakowskiemu

${ }^{2}$ B. Jakubowski, Michat Pawlikowski jako ziemianin - właściciel klucza medyckiego w latach 1919-1939, „Rocznik Przemyski. Historia”, t. 54, 2018, z. 1(21), s. 103-130.

${ }^{3}$ Centralne Państwowe Archiwum Historyczne Ukrainy we Lwowie [dalej: CPAH], zesp. 134, opis 2 , sygn. $501, \mathrm{k} .1$.

${ }^{4}$ Sąd Rejonowy w Przemyślu, Archiwum VI Wydziału Ksiąg Wieczystych, Większe posiadtości ziemskie [dalej: SRPrz], t. 23: Starzawa lwh 735, s. 533.

${ }^{5}$ Michał Pawlikowski (1887-1970), syna Jana Gwalberta i Wandy z Abramowiczów, pisarz i archiwista, redaktor pisma artystyczno-kulturalnego „Lamus”(1908-1913), wydawca „Biblioteki Medyckiej”(1925-1939), w okresie międzywojennym działacz i publicysta związany z obozem narodowym, ostatni właściciel Medyki.

${ }^{6}$ Jan Gwalbert Henryk Pawlikowski (1891-1962), brat Michała, pisarz i znawca folkloru góralskiego, autor opowieści Bajda o Niemrawcu i nieukończonej sagi góralskiej Cisonie, żołnierz, brał udział w I wojnie światowej i kampanii wrześniowej 1939 r., dwukrotnie żonaty: 1) z Marią Kossak, córką malarza Wojciecha, poetką, 2) z Austriaczką Walerią Konczyńską, tancerką, z którą miał córkę Iwonę.

${ }^{7}$ Rkps BJ, sygn. 11299 IV, k. 10; Baczmahą zwano dawny folwark Pawlikowskich na prawym brzegu rzeki Wiszni w obrębie gminy Małnów. J. G. Pawlikowski kupił go w 1892 r. od wuja Stanisława Pawlikowskiego z linii małnowskiej.

${ }^{8}$ Henryk Woźniakowski (1898-1970), syn Marcjana z Biórkowa (1854-1927) i Marii Rodakowskiej (1863-1936), córki malarza Henryka Rodakowskiego, malarz i hodowca koni, w 1919 r. poślubił w Zakopanem Wandę Janinę Pawlikowską (1895-1972), córkę Jana Gwalberta i Wandy z Abramowiczów; w latach 1919-1925 administrował folwarkami Pawlikowskich Medyka-Kopań, w latach 1921-1932 dzierżawił Starzawę, następnie majątek Widzów w woj. łódzkim, gdzie przeniósł ze Starzawy stadninę koni pełnej krwi angielskiej. 
Znaczny obszar majątku J. G. Pawlikowskiego w Starzawie stanowił zwarty kompleks łąk i podmokłych nieużytków - tzw. Błot, który rozciągał się w pradolinie Sanu na zachód od zabudowań wsi i sięgał do Kanału Bucowskiego, uregulowanego akwenu odwadniającego okoliczne pola i wpadającego do rzeki Wiszni, prawobrzeżnego dopływu Sanu9. Obszar ten nie przedstawiał walorów użytkowych, dlatego w 1923 r. H. Woźniakowski wysunął projekt zagospodarowania jego części przez założenie stawów rybnych ${ }^{10}$. Dzierżawca Starzawy porozumiał się w tej sprawie z inżynierem Julianem Wasilewskim z Warszawy, który w tamtym czasie współpracował już z Wincentym Rozwadowskim (1878-1941), pionierem rybołówstwa w Małopolsce Wschodniej, przy zakładaniu gospodarstwa stawowego w majątku Babin koło Kałusza ${ }^{11}$. Pomysł sprowadzał się do usypania wałów ziemnych i zalania obszaru Błot wodą doprowadzoną z Kanału Bucowskiego i spiętrzonej jazem rzeki Wiszni ${ }^{12}$. Z niewiadomych względów planów tych wówczas nie zrealizowano, a Wasilewski podjął współpracę z Michałem Pawlikowskim przy budowie stawów rybnych w Kniażycach (w 1925 r.) i w Szechyniach (w 1927 r.) ${ }^{13}$. Ponadto kontynuował prace w majątku Rozwadowskich w Babinie, projektując w 1927 r. jaz faszynowy na rzece Łomnicy w celu usprawnienia zasilania tamtejszych stawów rybnych w wodę ${ }^{14}$.

Właśnie z Wincentym Rozwadowskim, właścicielem dóbr w Babinie i głównym udziałowcem zawiązanej przez Wasilewskiego spółki rybackiej, Michał Pawlikowski konsultował na początku 1928 r. propozycje inżyniera i szwagra dotyczące mokradeł i łąk w Starzawie ${ }^{15}$. Jak to zostało wyżej napisane, Michał

${ }^{9}$ Kanał Bucowski, ciek płynący z okolic wsi Buców (obecnie na Ukrainie) do rzeki Wiszni, uregulowany ok. $1851 \mathrm{r}$. w celu odwodnienia gruntów, Wisznia to prawobrzeżny dopływ Sanu o długości 98 km. T. Misiak, op. cit., s. 37.

${ }^{10}$ Dziennik czynności osobistych Michała Pawlikowskiego z 1923 r., w zbiorach Kaspra Pawlikowskiego [dalej Dziennik MP], wpis z 2 VI.

${ }^{11}$ Zakład Narodowy im. Ossolińskich we Wrocławiu. Oddział Rękopisów [dalej ZNIO], sygn. 7948 II, t. 4-5, listy Wincentego Rozwadowskiego do Jana Rozwadowskiego: Babin 18 I 1923 r., k. 500, Babin 22 I 1923 r., k. 501; W 1937 r. stawy w Babinie zajmowały powierzchnię 172 ha. Rolnik 1867-1937, Lwów 1938, s. 160; Wincenty Jordan Rozwadowski (1878-1941), syn Bartłomieja powstańca styczniowego, brat polityka obozu narodowego Jana Emanuela Rozwadowskiego, kuzyn gen. Tadeusza Rozwadowskiego, współwłaściciel (wraz z bratem Janem) majątku Babin i Słobódka koło Kałusza w woj. stanisławowskim, członek Rady Nadzorczej Galicyjskiego Banku Ziemskiego, wicemarszałek powiatu kałuskiego i członek tamtejszej Rady Powiatowej, członek Galicyjskiego, a następnie Małopolskiego Towarzystwa Rolniczego, działacz Stronnictwa Narodowego, zmarł 14 X 1941 r. w Argentat we Francji. Nekrologia: „Myśl Polska”, nr z 15 XI 1941 r., s. 268; E. Rozwadowski, Historia rodziny Jordan Rozwadowskich, Wrocław 2015, s. 103-105.

${ }^{12}$ Dziennik MP z 1923 r., wpis z 18 VII i 12 VIII.

${ }^{13}$ Dziennik MP z 1925 r., wpisy z 7 I i 5 IV; Dziennik urzędowy województwa lwowskiego na rok 1927, nr 3, s. 5; Dziennik MP z 1927 i 1928 r., wpisy z 15 VIII 1927 r. i 16 VI 1928 r.

${ }^{14}$ We wrześniu 1927 r. W. Rozwadowski wniósł prośbę do starostwa w Kałuszu o wydanie konsensu wodnoprawnego na budowę jazu faszynowego na rzece Łomnicy. Dziennik urzędowy województwa stanisławowskiego na rok 1927, $\mathrm{nr} 10 \mathrm{z} 1 \mathrm{X}$, s. 4; ZNIO, sygn. 7948 II, t. 4-5, W. Rozwadowski do J. Rozwadowskiego, 20 III 1926 r., k. 520.

${ }^{15}$ Wasilewski współpracował w ramach spółki rybackiej również z H. Woźniakowskim. Dziennik MP z 1928 r., wpisy z 25 i 27 II. 
sprawował w tamtym czasie pieczę nad majątkiem ojca i poszukiwał najlepszych rozwiązań dla jego funkcjonowania. Perspektywy starzawskie były dla właściciela Babina na tyle atrakcyjne, że niebawem sam zgłosił swoją gotowość do uczestnictwa w interesie. Zainteresowanie Rozwadowskiego projektem nie było zresztą przypadkowe. Jan Gwalbert i Michał Pawlikowscy pozostawali bowiem w bliskich kontaktach z Janem ${ }^{16}$ i Wincentym Rozwadowskimi, stryjecznymi braćmi gen. Tadeusza Rozwadowskiego ${ }^{17}$, a spoiwem łączącym obie rodziny były zapatrywania ideologiczne (przynależność do obozu narodowego) oraz poglądy antysanacyjne. W 1920 r. Jan Rozwadowski, starszy brat Wincentego, zastąpił J. G. Pawlikowskiego na stanowisku prezesa Związku Ludowo-Narodowego w Małopolsce Wschodniej, a w 1922 r. współpracował z jego synem Michałem przy organizowaniu zaplecza politycznego narodowej demokracji przed wyborami parlamentarnymi. Po wyborach obaj wspóltworzyli we Lwowie komitet dzielnicowy Chrześcijańskiego Związku Jedności Narodowej i należeli do tajnej „Grupy X” (Związek Obrony Narodowej), działającej na rzecz Jedności z ramienia Związku Ludowo-Narodowego (członkiem tego gremium był również W. Rozwadowski). Ponadto współpracowali w strukturach lwowskiego Banku Ziemian i partycypowali w kosztach po jego upadku w 1927 r. Wreszcie Michał Pawlikowski gościł kilkakrotnie braci Rozwadowskich w Medyce, m.in. w kwietniu 1925 r. przy okazji zorganizowanego tam zjazdu członków Jedności Ziemiańskiej ${ }^{18}$. Nie bez znaczenia dla rodziny Pawlikowskich w kontekście planów starzawskich pozostawały też kwestie finansowe: potrzeba zrównoważenia budżetu rodzinnego i spodziewane zyski z interesu (W. Rozwadowski był osobą dość majętną).

Pierwsze rozmowy w przedmiotowej sprawie ruszyły na wiosnę 1928 r. Pod nieobecność M. Pawlikowskiego przebywającego za granicą, rokowania z W. Rozwadowskim prowadził z upoważnienia J. G. Pawlikowskiego, właściciela

${ }^{16}$ Jan Emanuel Rozwadowski (1878-1935), doktor prawa, docent habilitowany w dziedzinie ekonomii politycznej na Uniwersytecie Lwowskim, sekretarz generalny Naczelnego Komitetu Narodowego, współtwórca i członek Komitetu Narodowego w Paryżu, w 1919 r. członek delegacji polskiej na Konferencje Pokojową, członek Komitetu Głównego Stronnictwa Demokratyczno-Narodowego, w latach 1920-1928 prezes Związku Ludowo-Narodowego w Małopolsce Wschodniej, później prezes tamtejszego oddziału Stronnictwa Narodowego, dyrektor lwowskiego Banku Ziemian, od 1920 r. mieszkał we Lwowie przy ul Cłowej 3, właściciel odziedziczonego po żonie majątku Hładki w woj. tarnopolskim. E. Rozwadowski, op. cit., s. 90-93; P. Ruciński, Jan Emanuel Rozwadowski. Biografia polityka, działacza społecznego, uczonego (do 1914 r.), Łomianki 2020.

17 Tadeusz Rozwadowski (1866-1928), gen. broni Wojska Polskiego, szef Sztabu Generalnego WP w 1918 i 1920 r., dowódca Armii Wschód w czasie walk z Ukraińcami we Lwowie, jeden z głównych architektów zwycięstwa polskiego w czasie bitwy warszawskiej 1920 r., w czasie zamachu majowego 1926 r. opowiedział się po stronie legalnych władz Rzeczypospolitej, co przypłacił aresztowaniem i pobytem w więzieniu, zmarł niedługo po uwolnieniu i spoczął obok swych żołnierzy na Cmentarzu Orląt we Lwowie. M. Patelski, Generat broni Tadeusz Jordan Rozwadowski. Żotnierz i dyplomata, Warszawa 2002.

${ }^{18}$ Lwowska Naukowa Biblioteka im. W. Stefanyka [dalej: LNB], Zesp. 76, cz. III, sygn. 226, k.107. 
Starzawy, Adam Potocki ${ }^{19}$, dyrektor dóbr medyckich. Mimo absencji w kraju dziedzic Medyki chłonął informacje dochodzące ze Lwowa, a 18 IV 1928 r. przestrzegał ojca z odległego Monte Carlo:

Pisze mi Potocki, że robi się interes stawowy. Obawiam się, że Potocki nie będzie miał dość twardości wobec takiego orzecha jak Wincenty Rozwadowski. Niech Tatko Wickowi Rozwadowskiemu nie ustępuje [...] Musimy robić businessy dobrze, jeżeli się dziś mamy utrzymać na poziomie $[\ldots]^{20}$.

Po powrocie z zagranicy Michał wspierał ojca w pertraktacjach z W. Rozwadowskim i w trudnych momentach brał na siebie ciężar negocjacji. Te zaś nie były łatwe i ciągnęły się z przerwami do wiosny $1931 \mathrm{r}^{21} \mathrm{~W}$ początkowej fazie nie sprzyjała im również postawa $\mathrm{H}$. Woźniakowskiego, który forsował opcję samodzielnego wykonania stawów ${ }^{22}$. Początkowo J. G. Pawlikowski skłaniał się ku wydzierżawieniu Rozwadowskim terenu stawowego (28 III 1928 r. strony ustaliły wstępne warunki przyszłej arendy ${ }^{23}$ ), jednak za radą starszego syna zadecydował z czasem o jego sprzedaży ${ }^{24}$. Negocjacje przyśpieszyły jesienią 1929 r., tuż przed wyjazdem właściciela Babina za granicę 25 XI 1929 r. Jan Gwalbert uzgodnił z Wincentym Rozwadowskim kluczowe punkty przyszłej transakcji26, a już 13 XI zawarł z nim, w obecności syna Michała, umowę zobowiązującą obie strony

${ }^{19}$ Adam Potocki h. Pilawa (1883-1955), syn Włodzimierza z podolskiej linii Potockich, właściciela dóbr Smotrycz, i Marii Gradowskiej. Do I wojny światowej gospodarował we własnym majątku Smotrycz, w latach 1925-1932 administrował kluczem medyckim, następnie majątkiem J. G. Pawlikowskiego w Starzawie, który w 1937 r. objął w dzierżawę.

${ }^{20}$ LNB, zesp. 76, cz. III, sygn. 200, M. Pawlikowski do ojca Monte Carlo 18 IV 1928 r., k. 62.

${ }^{21} 2$ VII 1928 r. M. Pawlikowski gościł w Medyce J. Rozwadowskiego (Dziennik MP z 1928 r.), a 9 II 1929 r. spotkał się z J. i W. Rozwadowskimi we Lwowie. LNB, zesp. 76, cz. III, sygn. 418, A. Pawlikowska do B. Obertyńskiej, Zakopane 9 II 1929 r.; w listopadzie 1928 r. strony ustaliły wstępne warunki przyszłej umowy dzierżawnej: obszar ok. 600 morgów, czynsz 5000 dolarów (Rozwadowski optował za niższą ratą w pierwszych dwóch latach po rozpoczęciu robót ziemnych), odszkodowanie za obszar objęty pracami niwelacyjnymi. Dziennik MP z 1928 r., wpisy z 1 XI i 14 XI.

2214 I 1935 r. M. Pawlikowski przypominał o tym w liście do matki, Wandy z Abramowiczów. Rkps BJ, sygn. 11345 III, k. 11-12; Z zapisków J. G. Pawlikowskiego wynika, że początkowo H. Woźniakowski partycypował w kosztach interesu stawowego (do 1931 r. miał pokryć łącznie 24439 zł). LNB, zesp. 76, cz. III, sygn. 211, J.G. Pawlikowski, Stan dochodu i ksiąg 1933 r.; potwierdzają to również słowa z listu J.G. Pawlikowskiego do syna Michała z 5 VIII 1930 r. Rkps BJ, sygn. $12321 \mathrm{IV}, \mathrm{k} .74$.

${ }^{23} 20$ III 1929 r. J.G. i M. Pawlikowscy uzgodnili z W. Rozwadowskim warunki przyszłej dzierżawy terenu stawowego w Starzawie. W ciągu pierwszych pięciu lat Rozwadowski miał płacić 3 000 dolarów czynszu, a w kolejnych siedmiu latach -4000 dolarów. W przypadku zakupu gruntów Rozwadowski proponował cenę 100 dolarów za morgę, M. Pawlikowski żądał 120 dolarów. Dziennik MP z 1929 r., wpis z 29 III.

${ }^{24}$ M. Pawlikowski doradzał ojcu sprzedaż gruntów już 20 III 1929 r. Miesiąc później zaproponował W. Rozwadowskiemu zakup części obszaru dworskiego w Medyce (150-200 morgów roli, Górę Szechyńską i 200 morgów lasu Kosowica w Bucowie). Dziennik MP z 1929 r., wpis z 22 IV i 29 IV.

${ }^{25}$ Rozwadowski był m.in. w Kopenhadze i Dreźnie. ZNiO, sygn. 7948 II, t. 4-5, W. Rozwadowski do J. E. Rozwadowskiego, Babin 21 XII 1929 r., s. 537.

${ }^{26} \mathrm{~W}$. Rozwadowski chciał być właścicielem gruntu przeznaczonego pod kanał doprowadzający wodę z Wiszni i oddać Pawlikowskim służebności na nim. Dziennik MP z 1929 r., wpis z 7 XI. 
do kupna, a w przypadku niemożności - przewłaszczenia gruntów do dzierżawy części obszaru dworskiego w Starzawie ${ }^{27}$.

W tym miejscu należy sprostować informacje pojawiające się w różnych opracowaniach, jakoby już w 1929 r. W. Rozwadowski nabył od Pawlikowskich około 500-600 ha łąk i nieużytków w Starzawie ${ }^{28}$. Co prawda, w tamtym czasie strony związały się umową i zobowiązały do przeprowadzenia transakcji, jednak powodzenie interesu uzależniały od dopełnienia wszelkich formalności wodnoprawnych oraz zgody komisarza ziemskiego na sprzedaż i przewłaszczenie gruntów (przedsięwzięcie było bowiem planowane poza sprzedażą parcelacyjną).

Do końca września 1930 r. M. Pawlikowski i W. Rozwadowski doprecyzowali większość punktów związanych z wytyczeniem granic nowej posiadłości oraz $\mathrm{z}$ terminami płatności, jednak $\mathrm{w}$ dalszym ciągu oczekiwali decyzji opieszałych - ich zdaniem - urzędników. Jaką wagę dla przyszłości interesu miały werdykty miejscowych władz, świadczą słowa właściciela Babina z listu do M. Pawlikowskiego, pisanego z Babina 22 IX 1930 r.:

Zanim jakiekolwiek kroki w sprawie przewłaszczenia rozpoczniemy, musimy wyczekać definitywnego i prawnie ważnego otrzymania koncesji, bez której do kupna nie mógłbym przystąpić [...] Po otrzymaniu prawomocnej kaucji będę musiał porozumieć się z Tobą co do oznaczenia dróg dojazdowych i definitywnego oznaczenia granic nowej posiadłości, gdyż bez tego nie da się zrobić podania o pozwolenie na przewłaszczenie. Na razie nie pozostaje, zdaje się, nic innego, jak odczekanie otrzymania koncesji $[\ldots]^{29}$.

W tamtym czasie Rozwadowskiego zaniepokoiła również postawa Ludwika Myszkowskiego ${ }^{30}$, właściciela Stubna, który wdrażał w swoim majątku plany melioracyjne, wysunął pretensje względem ilości przepływu wody na rzece Wiszni i zażądał udziału w koncesji na mającym się budować jazie ${ }^{31}$.

${ }^{27}$ Dziennik MP z 1929 r., wpis z 13 XI.

${ }^{28}$ T. Epsztein, S. Górzyński, op. cit., s. 103; Informację powielono również na stronach internetowych, w tym Gospodarstwa Rybnego w Starzawie.

${ }^{29}$ LNB, zesp. 76, cz. III, sygn. 233, W. Rozwadowski do M. Pawlikowskiego, Babin 22 IX 1930 r., k. $17-18$.

${ }^{30}$ Ludwik Myszkowski h. Jastrzębiec, ur. 19 VII 1893 r. w Tymbarku jako syn Józefa i Jadwigi z Marszałkowiczów, absolwent Zakładu Jezuitów w Chyrowie, inż. rolnictwa (studia w Monachium), żołnierz 2 Pułku Ułanów Legionów Polskich, w szeregach którego odbył kampanię w Karpatach. Od 1916 r. odbudowywał ze zniszczeń wojennych majątek rodzinny w Stubnie (1222 ha), gdzie po 1918 r. postawił murowany dwór. W latach 1932-1939 był prezesem Oddziału Towarzystwa Rolniczego w Przemyślu, w latach 1936-1939 pełnił funkcję prezesa Lwowskiego Oddziału Małopolskiego Towarzystwa Rolniczego, był również radcą i członkiem zarządu Izby Rolniczej we Lwowie (1934, 1937-1939). Ponadto był udziałowcem „Ziemiańskiej Spółdzielni Mleczarskiej” w Przemyślu i od 1938 r. wiceprezesem rady nadzorczej przemyskiej Spółdzielni Handlowej „Rolnik”. Sympatyzował z J. Piłsudskiego i po 1928 r. z BBWR. W 1935 r. został wybrany do Rady Powiatowej w Przemyślu, a w 1937 r. odznaczono go Złotym Krzyżem Zasługi za działalność społeczną. Na wieść o wkroczeniu sowietów do Polski we wrześniu 1939 r. wyjechał do majątku siostry w Tymbarku (pow. limanowski), gdzie organizował struktury ZWZ AK. Zginał 18 III 1942 r., rozstrzelany przez Niemców w obozie koncentracyjnym w Oświęcimiu.

${ }^{31}$ LNB, zesp. 76, cz. III, sygn. 233, W. Rozwadowski do M. Pawlikowskiego, Babin 22 IX 1930 r. k. $17-18$. 
28 IX 1930 r. właściciel Babina przyjechał do Lwowa na decydującą - jak sądzono - konferencję z M. Pawlikowskim i A. Potockim. Kilka dni wcześniej Michał przebywał w Zakopanem, gdzie otrzymał od ojca instrukcje względem rozmów i pełnomocnictwo do sprzedaży również innych parcel z majątku Starzawa z Baczmahą oraz należących do Jana Gwalberta gruntów rustykalnych w Medyce, w Bucowie i w Kalnikowie ${ }^{32}$. Wydawało się, że wypracowane ustalenia zadowoliły obie strony i zbliżyły je do sfinalizowania interesu, tym bardziej że Rozwadowski dysponował już kompleksowym projektem urządzenia stawów autorstwa inżyniera Wasilewskiego ${ }^{33}$. Jeszcze tego samego dnia właściciel Medyki zrelacjonował przebieg rozmów w liście do ojca, przebywającego nadal w domu rodzinnym na Kozińcu w Zakopanem. Pisał w nim:

[...] 4-go starostwo wyśle do nas definitywną koncesję, którą zarząd prześle Rozwadowskiemu do wdrożenia kroków o przewłaszczenie. Podanie o przewłaszczenie adwokat Argasiński [dr Karol Argasiński ze Lwowa, pełnomocnik rodziny Rozwadowskich - B.J] wniesie zaraz po otrzymaniu koncesji i zrobieniu potrzebnej do podania szkicowej mapki [...] Prawdopodobnie podanie zostanie załatwione do kilku dni. Drobne delimitacje granic załatwi się po moim powrocie [...] Zgodziliśmy się co do dróg dojazdowych, że aby uniknąć ciągłych sporów o konserwację. Rozwadowski będzie miał osobną drogę własną równolegle obok naszej prowadzącej z rogu Zababin [grunty za Wisznią w kierunku Małnowa - BJ] do leśniczówki, przez którą to drogę przysługiwać nam będą przejazdy. Tak samo będziemy mieli mostki i przejazdy przez kanał. Co do kanału, to prosi nie o $10 \mathrm{~m}$ szerokości, ale o $15 \mathrm{~m}$ (naturalnie z drogą własną i kanał zapłaci od przestrzeni) $[\ldots]^{34}$.

Cenę kupna ustalono wstępnie na niespełna 59000 dolarów płatnych w trzech ratach, przy czym właściciel Babina zastrzegł dla siebie prawo uregulowania dwóch ostatnich spłat cesją jednej ze swych pretensji wekslowych ${ }^{35}$. Usatysfakcjonowany z rozmów M. Pawlikowski uważał interes za dopięty i wyjechał z żoną do Dalmacji. Tymczasem W. Rozwadowski, zniechęcony roszczeniami miejscowych włościan, którzy mieli żądać odszkodowania za przeprowadzony w pośpiechu zbiór siana $\mathrm{z}$ dzierżawionych dotąd przez siebie łą $\mathrm{k}^{36}$, opóźnił bieg sprawy i wyjechał za granicę. Michał Pawlikowski informował o tym fakcie szwagierkę, Beatę z Wolskich Obertyńską, ponieważ od sfinalizowania układu z Rozwadowskim uzależniał ewentualne zaangażowanie ojca w dalszą przebudowę „Zaświecia” - domu Wolskich

\footnotetext{
${ }^{32}$ Pełnomocnictwo z daty Zakopane 17 IX 1930 r. LNB, zesp. 76, cz. III, sygn. 206, k. 127.

${ }^{33}$ Projekt urządzenia stawów z 13 V 1930 r. sporządzony przez biuro robót melioracyjnych Juliana Wasilewskiego w Warszawie. Archiwum rodziny Rozwadowskich, mail E. Rozwadowskiego z 22 VI $2020 \mathrm{r}$.

${ }^{34}$ LNB, zesp.76, cz. III, sygn. 201, M. Pawlikowski do ojca, Lwów 28 IX 1930 r., k. 23-24.

${ }^{35} \mathrm{~W}$. Rozwadowski zobowiązał się do wpłaty pierwszej raty w dniu otrzymania zezwolenia na przewłaszczenie gruntów, drugiej - do pół roku, a ostatniej do końca roku od wpłaty pierwszej raty. Rozważał jednak spłatę zobowiązań wekslami Fedorowicza lub Szponerowej. LNB, zesp. 76, cz. III, sygn. 201, M. Pawlikowski do ojca, 28 IX 1930 r., k. 23-24; Rkps BJ, sygn. 12335 IV, W. Rozwadowski do M. Pawlikowskiego, Babin 16 I 1934 r., k. 126.

${ }^{36}$ Rkps BJ, sygn. 12335 IV, W. Rozwadowski do M. Pawlikowskiego, Babin 16 I 1934 r., k. 126.
} 
przy ul. Kaleczej 20a we Lwowie. Postawa Wincentego zaniepokoiła właściciela Medyki do tego stopnia, że interweniował w sprawie realizacji zapisów umowy u zaprzyjaźnionego Jana Rozwadowskiego ${ }^{37}$.

Ostatecznie obie strony doszły do porozumienia, a na początku kwietnia $1931 \mathrm{r}$. okręgowy komisarz ziemski we Lwowie zezwolił właścicielowi Starzawy na sprzedaż nieruchomości ${ }^{38}$. Zaraz też, 21 IV 1931 r., podpisano we Lwowie właściwy kontrakt kupna-sprzedaży części obszaru dworskiego w Starzawie i w Bucowie. Na jego podstawie J. G. Pawlikowski sprzedał W. Rozwadowskiemu i jego młodszym dzieciom, Tadeuszowi ${ }^{39}$ i Annie Nieszkowskiej ${ }^{40}$, obszar o powierzchni 414 ha 23 ar $23 \mathrm{~m}^{2}{ }^{41}$, obejmujący oprócz podmokłych łąk i pastwisk również sporą część dochodowego lasu, za około 58000 dolarów ${ }^{42}$. Właściciel Babina, który zastrzegł dla siebie $2 / 3$ praw do nabytych gruntów, zapłacił przy podpisaniu kontraktu nieco ponad 20000 dolarów. Resztę ceny kupna w kwocie 37 585,85 dolarów zaintabulowano na hipotece sprzedanych nieruchomości ${ }^{43}$, a nabywca zobowiązał się uregulować zadłużenie do kwietnia 1935 r. ${ }^{44}$ Senior rodu Pawlikowskich nie

${ }^{37}$ LNB, zesp. 76, cz. III, sygn. 419, M. Pawlikowski do B. Obertyńskiej, 25 IX 1930 r., k. 48; M. Pawlikowski był żonaty z Anielą Wolską (1901-1980), malarką, córką Wacława i Maryli Młodnickiej, siostrą Beaty Obertyńskiej. W 1929 r. zakończono niezbędny, ale kosztowny remont „Zaświeca” we Lwowie.

${ }^{38}$ Orzeczenie Okręgowego Urzędu Ziemskiego we Lwowie z 6 IV 1931 r. Archiwum Państwowe w Przemyślu [dalej APPrz.], zesp. 2400, sygn. 77, wpis lwh 1502, s. 62-63.

${ }^{39}$ Tadeusz Jordan Rozwadowski (1906-1989), absolwent Wyższej Szkoły Handlowej w Poznaniu, członek korporacji „Corona”, pracownik koncernu węglowego „Robur” z Katowic (od 1938 r. szef personalny i administracyjny koncernu), żołnierz, uczestnik kampanii wrześniowej w 1939 r., ranny pod Tomaszowem Lubelskim, kawaler orderu Virtuti Militari, żonaty z Janiną Dembińską, córką Bronisława, prof. Historii Uniwersytetu Poznańskiego. E. Rozwadowski, op. cit., s. 121-123; „Gazeta Kościelna” 1932, nr 4 z 24 I, s, 2

${ }^{40}$ Anna z Rozwadowskich Nieszkowska (1905-1953), żona Edmunda Nieszkowskiego, żołnierza WP, kawalerzysty, uczestnika kampanii wrześniowej 1939 r., w tamtym czasie mieszkała z mężem w Grudziądzu. E. Rozwadowski, op. cit., s. 120-121.

${ }^{41} \mathrm{Na}$ podstawie kontraktu z 21 IV 1931 r. L. Rep. 74295 J. G. Pawlikowski sprzedał Rozwadowskim z majętności w Starzawie parcele gruntowe: 6594/3 rola, 6599/8 las, 6604 las, 6605/1 łąka, 6605/2 łąka, 6605/3 łąka, 6606 rola i 6608 rola, a z gruntów rustykalnych Bucowa parcele: 1357 pastwisko1358 rola, 1359/2 pastwisko. W. Rozwadowski stał się formalnie właścicielem 2/3 niewydzielonych części nabytego majątku, Tadeusz i Anna objęli po 1/3 niewydzielonej części (w kontrakcie pominięto syna Bartłomieja, który w tamtym czasie praktykował w Zuszycach). SRPrz., t. 23: Starzawa lwh 735, s. 507-511, tamże L.1632 pod 23 VII 1931 r., s. 524; APPrz., zesp. 2400, sygn. 76, tamże, sygn. 77, k. 62-63; LNB, zesp.76, cz. III, sygn. 211, k. 98-100; nie odnalazłem mapy katastralnej Starzawy w zbiorach polskich archiwów.

${ }^{42} \mathrm{~W}$ kontrakcie przyjęto cenę 80 dolarów za morgę. LNB, zesp.76, cz. III, sygn. 211, k. 98; na tej podstawie autor przyjął cenę kupna na ok. 58000 dolarów; wśród zakupionych gruntów było 117 ha lasów.

${ }^{43}$ APPrz, zesp. 2400, sygn. 77, L. 1334 pod 21 V 1931 r., s. 64. O przeniesieniu na hipotekę reszty ceny kupna Jan Gwalbert, Michał i Jan Pawlikowscy informowali w artykule w „Słowie Narodowym" z 1937 r., nr 31 i 32. LNB, zesp.76, cz. III, sygn. 110, k. 14.

${ }^{44} \mathrm{Z}$ korespondencji W. Rozwadowskiego z M. Pawlikowskim wynika, że do stycznia $1934 \mathrm{r}$. właściciel Babina spłacił 2/3 ceny kupna w kwocie ok.40 000 dolarów. Ostatnią ratę w wysokości niespełna 19000 dolarów Rozwadowski miał spłacić w kwietniu 1935 r. Rkps BJ, sygn. 12335 IV, W. Rozwadowski do M. Pawlikowskiego, 16 I 1934 r., k. 126. 
skorzystał jednak z rady starszego syna, oddał Rozwadowskim resztę zadłużenia $\mathrm{w}$ formie pożyczki i nie zagwarantował sobie spłaty długu po kursie dolara w zło$\mathrm{cie}^{45}$. Decyzja ta miała swoje reperkusje w przyszłości.

Na zakupionych gruntach Rozwadowscy utworzyli nowe ciało hipoteczne o nazwie Starzawa Stawy ${ }^{46}$, przemianowane niebawem na Nowostawy (w odróżnieniu od „starych" stawów w Babinie $)^{47}$, a W. Rozwadowski założył tam przy pomocy Juliana Wasilewskiego duże gospodarstwo rybne. Groble były usypywane, a stawy ze śluzami i mnichami były zasilane wodą doprowadzoną blisko 2,5 kilometrowym kanałem ze spiętrzonej jazem rzeki Wiszni oraz z potoku Krzywula (parcela z kanałem pozostała formalnie własnością Pawlikowskich, jednak ciążyło na niej prawo służebności na rzecz właścicieli Nowostawów ${ }^{48}$ ). Perspektywa zarobku w czasach targanych kryzysami ekonomicznymi przyciągała do Starzawy robotników z odległych nawet miejscowości. W zbiorach rodziny Rozwadowskich zachowały się unikatowe fotografie, które dokumentują poszczególne etapy powstawania gospodarstwa w Nowostawach, w tym budowę w 1932 r. jazu na Wiszni (na jednym ze zdjęć widać braci Wincentego i Jana Rozwadowskich na tle konstrukcji) ${ }^{49}$.

W 1932 r. W. Rozwadowski przekazał administrację majątku starszemu synowi Bartłomiejowi ${ }^{50}$, inżynierowi rolnictwa (był absolwentem Wydziału Rolno-Leśnego Uniwersytetu Poznańskiego, studiował też w Berlinie ${ }^{51}$ ), który praktykował dotąd na dzierżawie w Zuszycach koło Gródka Jagiellońskiego ${ }^{52}$. Ten osiadł w Nowostawach z żoną Anną (1906-1991), córką Józefa Jurystowskiego i bratanicą Edmunda, pierwszego wojewody stanisławowskiego ${ }^{53}$, i zarządzał dobrami do października 1939 r., kiedy został aresztowany przez NKWD ${ }^{54}$. W centrum ośrodka Bartłomiej

${ }^{45}$ Rkps BJ, sygn. 11345 III, M. Pawlikowski do matki, Zakopane 14 I 1935 r., k. 11-12; Rkps BJ, sygn. 11919 IV, M. Pawlikowski do W. Rozwadowskiego, Zakopane 20 lub 28 I 1935 r., k. 54-55.

${ }^{46}$ Majętność Rozwadowskich została wpisana pod lwh 533a księgi grodzkiej gminy katastralnej Starzawa przy Sądzie Grodzkim w Mościskach i lwh. 1502 ks. gr. gm. kat. Buców-Marynka Polska. APPrz., zesp. 2400, sygn. 77, L. 1334 pod 21 V 1931 r., s. 62; SRPrz., t. 23: Starzawa lwh 735, L.971 pod 26 III 1932 r., s. 524; LNB, zesp. 76, cz. III, sygn. 211, k. 98.

${ }^{47}$ E. Rozwadowski, op. cit., s. 105.

${ }^{48}$ SRPrz., t. 23: Starzawa lwh 735, s. 507-511, tamże L.1203 pod 21 VI 1935 r., s. 549.

${ }^{49}$ www.rozwadowski.org/v2.0.1.2/index.php/2015/07/21/w-nowostawach-1930-1939 [dostęp 10 III 2020 r.].

${ }^{50}$ B. Rozwadowski, ur. 7 V 1904 r. w Kozłowie jako syn Wincentego i Elżbiety ze Skarbek-Kruszewskich.

${ }^{51}$ Rozwadowski ukończył studia w 1928 r., w latach 1925-1927 prezesem korporacji studentów UP „Corona”. Wcześniej uczęszczał do prywatnego Gimnazjum Humanistycznego im. H. Jordana we Lwowie.

${ }^{52}$ K. Jasiewicz, Lista strat ziemiaństwa polskiego 1939-1956, Warszawa 1995, s. 887-888.

${ }_{53}$ Edmund Jurystowski (1873-1956), absolwent Wydziału Prawa Uniwersytetu Lwowskiego, urzędnik państwowy, starosta tarnopolski w 1920 r., wojewoda stanisławowski w latach 1921-1925, kawaler Krzyża Komandorskiego Orderu Odrodzenia Polski (1924 r.), współwłaściciel majątku Kurowce w woj. tarnopolskim. Jurystowski Edmund, [w:] Kto byt kim w Drugiej Rzeczypospolitej, red. J. M. Majchrowski, Warszawa 1994, s. 168.

${ }^{54}$ E. Rozwadowski, op. cit., s. 107. 
Rozwadowski postawił piętrowy dom w stylu angielskim, wybudowany w latach 1932-1933 według projektu architekta Jaroszyńskiego ${ }^{55}$, a w 1937 r. prowadzone przez niego gospodarstwo rybne zostało objęte nadzorem stacji kontroli zdrowotności ryb lwowskiej izby rolniczej ${ }^{56}$. W celu usprawnienia dostawy ryb dla kontrahentów w całej Polsce, w sierpniu 1935 r. B. Rozwadowski (formalnie jego żona Anna) zakupił od M. Pawlikowskiego parcele w pobliżu stacji kolejowej w Medyce ${ }^{57}$. Do wybuchu II wojny światowej wykorzystywano je m.in. jako kolejową składnicę towarów. Oprócz administrowania majątkiem ziemskim młody Rozwadowski udzielał się publicznie. Był członkiem, a od 9 IX 1938 r. prezesem lwowskiego oddziału Związku Zawodowego Rolników i Leśników z Wyższym Wykształceniem $^{58}$, a także członkiem Polskiego Związku Lowieckiego (w 1939 r. pełnił funkcję podłowczego powiatu mościskiego) ${ }^{59}$. Ponadto aktywnie uczestniczył w pracach Związku Ziemian i Stronnictwa Narodowego ${ }^{60}$.

Sprzedaż Rozwadowskim części obszaru dworskiego nie osłabiła znacznie majątku J. G. Pawlikowskiego w Starzawie (w 1937 r. obejmował jeszcze 1094 ha $^{61}$ ), pozwoliła natomiast zredukować część ciążących na nim zobowiązań podatkowych ${ }^{62}$; wpływy z pierwszej raty Rozwadowskich spożytkowano w pierwszej kolejności na oczyszczenie hipoteki sprzedanych nieruchomości ${ }^{63}$. W tym miejscu trzeba podkreślić, że operację starzawską sfinalizowano w czasie postępującego kryzysu ekonomicznego, który odbił się niekorzystnie na kondycji finansowej wielu majątków ziemskich. Nie dziwi zatem, że obie strony szukały sposobności, by wyjść z interesu z jak najkorzystniejszym bilansem. J. G. Pawlikowski, który nadal potrzebował pieniędzy na spłatę zaległości podatkowych, skorzystał z zapisu kontraktu ${ }^{64} \mathrm{i}$ we wrześniu $1933 \mathrm{r}$. zlecił ponowny pomiar sprzedanych gruntów. Okazało się, że Rozwadowscy posiedli 4 morgi ziemi więcej, dlatego w już styczniu

${ }^{55}$ Ibidem, s. 105. W 1932 r. B. Rozwadowski zamierzał tymczasowo wynająć od M. Pawlikowskiego willę na wyspie w Medyce. Rkps BJ, sygn. 12335 IV, k. 91-91v, B. Rozwadowski do M. Pawlikowskiego, Lwów 26 I 1932 r.; LNB, zesp.76, cz. III, sygn. 227, J. Rozwadowski do M. Pawlikowskiego, Lwów 28 II 1932 r., k. 108v. s. 157.

${ }^{56}$ Sprawozdanie z działalności lwowskiej izby rolniczej na rok budżetowy 1936/37, Lwów 1938,

${ }^{57}$ Formalnym nabywcą parcel gruntowych 5406-5414/1 (46,88 a), była Anna Rozwadowska, żona Bartłomieja. Cena kupna wyniosła 3300 zł. APPrz., zesp.1010, sygn. 5, nr rep. 721/35 z 19 VIII 1935 r., s. 427.

${ }^{58}$ „Gazeta Rolnicza” 1938, nr 38 z 23 IX, s. 1113; f J. Socha, Polski Zawodowy Zwiąek Rolników i Leśników z Wyższym Wyksztatceniem (1919-1939), „Acta Universitatis Lodzensis” 1990, nr 38, s. 96.

${ }^{59}$ Kalendarz Myśliwski na rok 1939, pod red. W. Garczyńskiego, Warszawa 1939, s. 380.

${ }^{60}$ np. 4 III 1938 r. uczestniczył w zebraniu Ziemian Narodowych we Lwowie. LNB, zesp. 76, cz. III, sygn. 226, k. 4.

${ }^{61}$ Rkps BJ, sygn. 11299 IV, k. 43.

${ }^{62} \mathrm{~W}$ maju 1931 r. na dobrach Starzawa ciążyło 30 825,83 zł tytułem zaległych podatków. SRPrz., t. 23: Starzawa lwh. 735, wpis L. 1521 pod 28 VIII 1930 r., s. 547, wpis L. 1036 pod 9 V 1931 r., s. 547.

${ }^{63}$ Ibidem, wpis L. 971 pod 26 III 1932 r., s. 547.

${ }^{64}$ LNB, zesp.76, cz. III, sygn. 211, k. 98. 
1935 r. przemyski adwokat Zygmunt Szłapacki, pełnomocnik właściciela Starzawy, wezwał ich do zapłaty 271,30 dolarów rekompensaty ${ }^{65}$.

Koszty związane z budową gospodarstwa rybnego (około pół miliona zł), jak również nieoczekiwany spadek cen ryb, nadszarpnęły budżet W. Rozwadowskiego na tyle, że sprawa uregulowania jego długu wobec J. G. Pawlikowskiego przeciągnęła się o kilka lat ${ }^{66}$. Do stycznia 1934 r. właściciel Babina zdołał spłacić 2/3 ceny kupna (niespełna 40000 dolarów), jednak miał problemy z rozliczeniem się z pozostałych 19000 dolarów (skądinąd do końca 1936 r. Rozwadowski płacił Pawlikowskiemu oddzielną półroczną ratę odsetkową w wysokości 1200 zł ${ }^{67}$ ). O swojej sytuacji finansowej Wincenty poinformował M. Pawlikowskiego w liście z 16 I 1934 r. Korespondencja ta rzuca również światło na kulisy negocjacji starzawskich, z których wynika, że powodzenie transakcji wisiało w pewnej chwili na włosku:

Kochany Michale [...] Co do siły dolara, to przypominam sobie, żeś o możliwości jego zachwiania wspominał, ale nigdy sprawa ta nie była ani przez Ciebie, ani przez Twego Ojca stawianą jako żądanie i na pewno nie byłbym się na to zgodził. Sam wiesz, żem całą siłą pragnął, by do sfinalizowania kupna nie doszło. Wobec przejęcia przez Ojca Twego mych propozycji, musiałem interes uważać za skończony. Mimo fatalnej koniunktury i spadku ceny na 1/3 starałem się wszystkimi siłami zobowiązaniom mym zadość uczynić, co dotychczas z dość wielkim trudem się udaje, ale jak to już wtedy przewidywałem, cała kalkulacja mnie zawiodła i interes okazał się fatalnym [...] wykonanie (kosztem pół miliona) stawów, liczone na poprzednią koniunkturę i ceny, zachwiało mym stanem finansowym $[\ldots]^{68}$.

W połowie lat 30. XX w. doszło istotnie do załamania kursu dolara ${ }^{69}$. Wincenty Rozwadowski skorzystał z wprowadzonych naprędce przepisów dotyczących oddłużenia rolnictwa ${ }^{70}$, poddał konwersji swój dług wobec J. G. Pawlikowskiego i zaczął go spłacać listami zastawnymi Towarzystwa Kredytowego Ziemskiego. Wskutek takiego działania suma dłużna powstała z tytułu niespłaconej reszty ceny

${ }^{65}$ Pomiar przeprowadzony 22 IX 1933 r. przez inż. L. Malza wykazał, że Rozwadowscy przejęli w rzeczywistości 416 ha 18 a $40 \mathrm{~m}^{2}$ (723 m. 343 s.). LNB, zesp.76, cz. III, sygn. 211, L. Malz do Zarządu dóbr Starzawa, Przemyśl 22 IX 1933 r., k. 101; Rkps BJ, sygn. 11918 IV, k.228; LNB, zesp.76, cz. III, sygn. 211, k. 98-100, pozew adwokata Z. Szłapackiego do Sądu Okręgowego w Przemyślu, list Z. Szłapackiego o J. G. Pawlikowskiego, Przemyśl 22 II 1935 r. W. Rozwadowski scedował sprawę rozstrzygnięcia sporu na syna Bartłomieja i adwokata K. Argasińskiego. Rkps BJ, sygn. 12335 IV, W. Rozwadowski do M. Pawlikowskiego, Babin 16 I 1934 r., k. 126. Leopold Malz, mierniczy przysięgły w Przemyślu, zmarł w 1939 r.

${ }^{66}$ W. Rozwadowski stracił m.in. na wierzytelnościach Fedorowiczów i Szponerowej, którymi zresztą chciał pokryć część swego długu wobec J. G. Pawlikowskiego. Rkps BJ, sygn. 12335 IV, W. Rozwadowski do M. Pawlikowskiego, Babin 16 I 1934 r., k. 126.

${ }^{67}$ LNB, zesp.76, cz. III, sygn. 203, W. Rozwadowski do J.G. Pawlikowskiego, Babin 17 II 1935 r., k. 119; Rkps BJ, sygn. 11918 IV, k. 246, Raport Adama Potockiego ze Starzawy, 18 VII 1935 r.

${ }^{68}$ Rkps BJ, sygn. 12335 IV, W. Rozwadowski do M. Pawlikowskiego, Babin 16 I 1934 r., k. 126.

${ }^{69}$ Z kursu 8,9 zł za dolara w 1931 r. do kursu 5,3 w 1935 r. www.dobroni.pl, dostęp 25 III 2013 r.

${ }^{70}$ Rozporzadzenie Prezydenta Rzeczypospolitej Polskiej z dnia 24 X 1934 r. o konwersji i uporządkowaniu długów rolniczych, Dz. U. 1950 nr 94, poz. 840,841. 
kupna zdezawuowała się do poziomu niespełna 30-40\% wartości pierwotnej ${ }^{71}$. Rozwadowski tłumaczył się z takiego postępowania w liście do swego wierzyciela z 5 III 1935 r.:

Jaśnie Wielmożny Panie Profesorze [...] sam uważam całe rozporządzenie o konwersji za w wysokim stopniu niesprawiedliwe i wierzyciela krzywdzące, sam też jestem w największym stopniu nim dotknięty [...] Cały mój kapitał na kupno Starzawy przeznaczony, ulokowany był w dolarach na hipotekach ziemskich. Od pięciu z wyż lat nie wpłacono mi ani grosza z tytułu odsetek, ani nic na kapitał, do tego przyszły jeszcze nieoczekiwane straty w samej Starzawie i zmiana dochodowości gospodarstw stawowych. Ani ja, ani moje dzieci, jako współwłaściciele, nie rozporządzają płynną gotówką, która pozwalałaby resztę ceny kupna wypłacić gotówką. Wobec tego musiałem zdecydować się na wniesienie podania do TKZ o przeprowadzenie konwersji i spłacenie długu listami $[\ldots]^{72}$.

Do opisanej sytuacji doszło w chwili trudnej dla J. G. Pawlikowskiego. Wprawdzie jego majątek w Starzawie nie był obciążony względem instytucji kredytowych, jednak sen z powiek właściciela spędzały narastające zaległości podatkowe ${ }^{73}$. Konieczność ich natychmiastowej spłaty w czasie kryzysu gospodarczego nadwyrężyła kondycję finansową właściciela Starzawy. W ramach oszczędności Pawlikowski przeniósł się na przełomie lat 1934 i 1935 z obszernego mieszkania w kamienicy przy ul. Trzeciego Maja 5 we Lwowie (ta przeszła w tamtym czasie własność Zakładu Ubezpieczeń od Wypadków) do willi Wolskich przy ul. Kalecza 20a ${ }^{74}$, a w kwietniu 1935 r. zawnioskował do zarządu miejskiego o rozłożenie na raty podatku od zbytku mieszkaniowego ${ }^{75}$. Michał Pawlikowski, który nie nadzorował już bezpośrednio spraw majątkowych ojca (tymi zajmował się w tamtym czasie A. Potocki), robił wszystko, by uchronić go przed nieprzyjemnościami. Uważał Jana Gwalberta, członka Polskiej Akademii Umiejętności, za wiodący umysł ówczesnej Polski i nie chciał nadszarpnąć jego autorytetu. W tej sytuacji nie dziwi ton listu właściciela Medyki, pisanego do W. Rozwadowskiego w styczniu 1935 r., w którym przedstawiał interlokutorowi trudną sytuację materialną ojca i wzywał go do uregulowania zaległości, względnie pilnego podżyrowania mu nowej pożyczki:

Kochany Wicku [...] Zacznę od przytoczenia Ci wyjątków z listu mego Ojca, który dziś otrzymałem: Ze sprawami majątkowymi jest źle. Grosza nie ma, a pożyczki dostać nie można. W M.K.O. [Małopolska Kasa Oszczędności - B.J] robili nadzieję,

${ }^{71}$ Jan Gwalbert, Michał i Jan Pawlikowscy, Co się stało z pieniędzmi z parcelacji gruntu?, „Słowo Narodowe" 1937, nr 32, s. 4.; LNB, zesp.76, cz. III, sygn. 110, k. 14.

${ }^{72}$ LNB, zesp.76, cz. III, sygn. 203, W. Rozwadowski do J. G. Pawlikowskiego, 5 III 1935 r., k. 118.

${ }^{73} 18$ XII 1934 r. dobra Starzawa obciążone były sumą 44 776,05 zł na rzecz Skarbu Państwa, a 2 V 1935 r. zobowiązania wzrosły o kolejne 19 692,55 zł. SRPrz., t. 23: Starzawa lwh 735, L. 2812 pod 18 XII 1934 r., s. 548, L. 851 pod 2 V 1935 r., s. 548.

${ }^{74}$ Dziennik/Skoroszyt MP z lat 1934-1935 ze zbiorów K. Pawlikowskiego; LNB, zesp.76, cz. III, sygn. 203, Ziemski Bank Kredytowy do J.G. Pawlikowskiego, Lwów 9 VIII 1934 r., k. 81, Zakład Ubezpieczeń od Wypadków do J.G. Pawlikowskiego, Lwów 30 VIII 1934 r., k. 82.

${ }^{75}$ LNB, zesp.76, cz. III, sygn. 211, k. 89. 
jednak nie przyjmą żyra Jasia, dlatego że żyruje Twój weksel, który jest nieuregulowany i żądają nań spłaty 2500 zł. Innych żyrantów nie mam. Władza skarbowa grozi licytacją gruntów i dała termin do 3/2. Oczywiście do tego czasu znikąd pieniędzy nie będzie [...] Jedyny rachunek byłby w sprzedaży Kozińca, choć nikt nie kupi za cenę choćby przybliżoną do wartości. O ile by Rozwadowski jeszcze raty nie zapłacił gotówką, to byłby już w ogóle koniec. Najlepiej by było wyprowadzić się. Zaczynam to już robić $[\ldots]$. Na razie zrezygnowałem $z$ Wierchów [... $]^{76}$.

J. G. Pawlikowskiemu udało się w końcu wybrnąć z tarapatów, jednak okupił to koniecznością zaciągnięcia zobowiązań finansowych w Banku Rolniczym i Galicyjskiej Kasie Oszczędności ${ }^{77}$ oraz stopniowej parcelacji ziemi w Starzawie ${ }^{78}$.

W drugiej połowie 1935 r. również sytuacja finansowa W. Rozwadowskiego poprawiła się na tyle, że rozważał powiększenie majątku w Nowostawach o zwarty kompleks lasu. Początkowo był zainteresowany zakupem 150-300 morgów drzewostanu w samej Starzawie ${ }^{79}$, jednak pod koniec 1936 r. M. Pawlikowski przekonał go do nabycia lasu Kosowica w Bucowie, obejmującego około 177 ha. Interes ten był częścią składową większej transakcji, mającej na celu oddłużenie dóbr Pawlikowskich w Bucowie. Nie miejsce tu przedstawiać szczegółów dotyczących tej skomplikowanej operacji - te zostały przedstawione w wymienionym artykule o działalności gospodarczej M. Pawlikowskiego ${ }^{80}$. Dość powiedzieć, że za pieniądze Rozwadowskich (50 000 zł) podstawiona przez męża Aniela Pawlikowska nabyła na licytacji majętność Buców, a 28 XII 1936 r. przelała zgodnie z zawartym wcześniej porozumieniem połowę swych praw do Bucowa (Kosowica) na rzecz wspomnianego W. Rozwadowskiego i jego synów: Bartłomieja i Tadeusza. Cała ta skomplikowana operacja została zatwierdzona postanowieniem o przybiciu Sądu Grodzkiego w Przemyślu 17 I 1937 r. ${ }^{81}$ Ok. 1938 r. W. Rozwadowski przestał się formalnie zajmować Nowostawami i scedował na rzecz synów swoje prawa majątkowe do gospodarstwa, powiększonego już o zwarty kompleks lasu Kosowica (3/5 praw do majątku otrzymał pierworodny Bartłomiej $)^{82}$. Nie wiadomo, czy przejęcie Kosowicy miało bezpośredni związek z uregulowaniem zobowiązań Rozwadowskich wobec J. G. Pawlikowskiego, zbiegło się jednak w czasie z zawarciem ugody w tej sprawie pomiędzy właścicielem Starzawy a Wincentym Rozwadowskim $^{83}$. W marcu 1937 r. adwokat Karol Argasiński, ówczesny plenipotent

${ }^{76}$ Rkps BJ, sygn. 11919 IV, M. Pawlikowski do W. Rozwadowskiego, Zakopane 20 lub 28 I 1935 r., k. 54-55.

${ }^{77}$ SR Prz., t. 23: Starzawa lwh 735, L. 1106 pod 7 VI 1935 r., s. 549, L. 198 pod 29 I 1936 r., s. 551.

${ }^{78}$ APPrz., zesp.1014, sygn. 9, k. 88v-89.

${ }^{79}$ Rkps BJ, sygn. 11918 IV, k. 230v.

${ }^{80}$ B. Jakubowski, op. cit., s.103-130.

${ }^{81}$ Ibidem, s. 122-123. Rozwadowski zakupił wówczas p.gr. 1493/1, 1493/6, 1494/1, obejmujące 176 ha 93 a $89 \mathrm{~m}^{2}$ lasu i 55 a $78 \mathrm{~m}^{2}$ roli. Arkusz posiadłości lwh $1286 \mathrm{ks}$. gr. Buców w Archiwum prywatnym Rozwadowskich, mail E. Rozwadowskiego z 22 VI 2020 r.

${ }^{82}$ Pamiętnik Tadeusza, syna Wincentego Rozwadowskiego, w: www.rozwadowscy.org

${ }^{83}$ „Słowo Narodowe” 1937 nr 32, s. 4; LNB, zesp.76, cz. III, sygn. 110, k. 14. 
Rozwadowskich, wystąpił do Jana Gwalberta o ekstabulację reszty ceny kupna ciążącej na nieruchomościach w Nowostawach ${ }^{84}$, a już 21 VIII 1937 r. zadłużenie wykreślono z ksiąg wieczystych ${ }^{85}$.

W tamtym czasie M. Pawlikowski dopinał już w porozumieniu z W. Rozwadowskim nowy interes, tym razem ze spółką naftową „Gazolina” z Borysławia. W maju 1937 r. Pawlikowski zawarł z „Gazoliną” kontrakt naftowy, odstępując jej odpłatnie ze swych majętności w Medyce i w Szechyniach prawo poszukiwania i wydobywania olejów skalnych ${ }^{86}$. Podobnie Michał zamierzał uczynić z majątkiem żony w Bucowie, dlatego zaproponował W. Rozwadowskiemu podpisanie odrębnej umowy na Kosowicę, co miało być korzystne finansowo dla obu posiadłości leżących w obrębie gminy katastralnej Buców ${ }^{87}$. Na podstawie zapisków M. Pawlikowskiego można domniemywać, że Rozwadowski przyjął ofertę sąsiada i dołączył do interesu. Pewne jest, że 1 VI 1937 r. „Gazolina” nabyła prawo do poszukiwania olejów skalnych w Bucowie Pawlikowskich, gdzie z czasem utworzono nowe ciała hipoteczne o nazwach „pola naftowe Buców I-VI"88.

Dobrosąsiedzkie relacje pomiędzy przedstawicielami obu rodzin utrzymywały się aż do pamiętnego września 1939 r., co znajduje odzwierciedlenie w zapiskach M. Pawlikowskiego i wspomnieniach jego syna Kaspra ${ }^{89}$. Wiosną 1937 r. Pawlikowski korzystał na przykład z pomocy inż. Franciszka Rozwadowskiego, syna Jana Emanuela, w pracach nad podniesieniem sadownictwa w swoich majątkach w Medyce i w Szechyniach. W tamtym czasie M. Pawlikowskiego zainteresowały perspektywy związane z rozbudową Centralnego Okręgu Przemysłowego, dlatego podjął kroki zmierzające do budowy w swych dobrach przetwórni owoców ${ }^{90}$.

Czasy prosperity Nowostawów trwały zaledwie kilka lat. Mimo to B. Rozwadowski rozwinął je w dobrze prosperujący majątek ziemski, a obfitość ptactwa wodnego ściągała tam amatorów polowań z całego kraju. We wrześniu 1939 r. Rozwadowski, oficer rezerwy, nie został zmobilizowany do wojska (chorował na cukrzycę) i pozostał z rodziną w Nowostawach, gdzie tworzył struktury lokalnej

${ }^{84} 20$ III 1937 r. reprezentujący W. Rozwadowskiego adwokat Karol Argasiński ze Lwowa zwrócił się do J. G. Pawlikowskiego o wykreślenie prawa zastawu zaintabulowanego na realności obj. whl 533a i 1502. LNB, zesp.76, cz. III, sygn. 209, k. 30. Kwit z zezwoleniem nosił datę 15 III 1937 r. APPrz., zesp. 2400, sygn.77, s. 64.

${ }^{85} 15$ III 1937 r. J. G. Pawlikowski zezwolił na wykreślenie prawa zastawu z hipoteki Nowostawów, a 21 VIII 1937 r. zaintabulowano wykreślenie prawa zastawu dla opisanej kwoty w księgach wieczystych. APPrz., zesp. 2400, sygn. 77, L. 2224 pod 21 VIII 1937 r., s. 64.

${ }^{86}$ Rkps BJ sygn. 11916 IV, k. 50-57.

${ }^{87}$ Dziennik/Skoroszyt MP z 1937 r. ze zbiorów K. Pawlikowskiego.

${ }^{88}$ SRPrz., t. 13, lwh 385 Starzawa, L. 1332 z 17 VI 1939 r., s. 18.

${ }^{89}$ LNB, zesp. 76, cz. III, sygn. 226, k. 179; K. Pawlikowski, Z Medyki. Wspomnienia rodzinne, Kraków 2017, s. 24.

${ }^{90}$ Rkps BJ, sygn. 11917 IV, k. 2-3; Franciszek Rozwadowski (1910-1990), syn Jana Emanuela, inżynier rolnictwa o specjalności sadownictwo, odziedziczył po ojcu majątek Hładki w woj. tarnopolskim. Dziennik/skoroszyt MP z 1937 r. w zbiorach K. Pawlikowskiego. 
samoobrony $^{91}$. Tam zastała go inwazja wojsk sowieckich. W nocy 15/16 X 1939 r. został zatrzymany w swym domu przez NKWD i osadzony w więzieniu w Mościskach, skąd zbiegł. Po ponownym zatrzymaniu i uwięzieniu w Przemyślu, w maju 1940 r. prawdopodobnie wywieziono go do ZSRR i od tamtej pory ślad po nim zaginął. Po aresztowaniu męża Anna Rozwadowska opuściła z dziećmi Nowostawy i po krótkiej tułaczce schroniła się w Krakowie, gdzie doczekała końca wojny. Ojciec Bartłomieja, Wincenty Rozwadowski, wyjechał we wrześniu 1939 r. przez Węgry do Francji. Zmarł na obczyźnie w 1941 r. ${ }^{92}$ Pod nieobecność właścicieli majątek w Nowostawach został rozgrabiony, a dwór spalony ${ }^{93}$. O chlubnej przeszłości tego miejsca przypominają dziś użytkowane nadal stawy, starodrzew dębowy w centrum dawnego ośrodka dworskiego i piętrowy budynek administracyjny ,powstały po wojnie na fundamentach domu Rozwadowskich.

\section{Bibliografia:}

Źródla archiwalne:

Archiwum prywatne Kaspra Pawlikowskiego w Krakowie:

Dziennik czynności osobistych Michała Pawlikowskiego z lat 1923, 1925, 1927-1930

Skoroszyt Michała Pawlikowskiego z lat 1934-1935, 1937

Archiwum prywatne Erazma Rozwadowskiego w Gliwicach:

Spis dokumentów dotyczacych majątku Nowostawy w zbiorach rodziny Rozwadowskich

Archiwum Państwowe w Przemyślu:

zesp. 1010 Akta notariusza Stanisława Ziemnowicza w Przemyślu, sygn. 5 Akta notarialne oznaczone numerami repertorium 513-799

zesp. 1014 Akta notariusza Adolfa Nitarskiego w Przemyślu, sygn. 9 Repertorium 1/37-738/37, $2 / 38-551 / 38$

zesp. 2400 Zbiór ksiag gruntowych skompletowanych przez sądy w Przemyślu, sygn. 77 Księa gruntowa gminy katastralnej Buców, okręg sądowy Przemyśl, lwh 1480-1529

Biblioteka Jagiellońska. Oddział Rękopisów:

rkps 11299 IV Papiery majątkowe J. G. Pawlikowskiego dotyczace majątków Starzawa i Baczmacha rkps 11345 III Korespondencja W. Pawlikowskiej z lat 1890-1964, t.12: listy syna Michała z lat $1897-1959 / 1960$

rkps 11395 III, Materiaty do biografii J. G. H. Pawlikowskiego

rkps 11916 IV, Papiery finansowe i majątkowe M. Pawlikowskiego jako właściciela Medyki

rkps 11918 IV, Pawlikowski Michat. Własne interesa gospodarcze: Medyka i Starzawa

${ }^{91}$ B. Rozwadowski był por. rez. 9 pułku ułanów (służba 1922/1923 r.). E. Rozwadowski, op. cit., s. 105; K. Jasiowicz, op. cit., s. 888.

${ }^{92}$ E. Rozwadowski, op. cit., s. 107.

${ }^{93} \mathrm{~W}$ okolicy grasowali nacjonaliści ukraińscy, którzy w kwietniu 1944 r. zamordowali trzech Polaków zatrudnionych w Zarządzie Stawów Rybnych. A. Zapałowski, Granica w ogniu. 35 ,Przemyska" Komeda odcinka WOP w działaniach przeciw OUN $i$ UPA w latach 1945-1948, Warszawa 2016, s. 144. 
rkps 11917 IV, Papiery gospodarcze M. Pawlikowskiego dotyczące sadów i parku w Medyce rkps 11919 IV, Fragment korespondencji M. Pawlikowskiego w sprawach majątkowych. Medyka, Buców, Szechynie i Starzawa

rkps 12321 IV, Korespondencja M. Pawlikowskiego, t. 62: Listy ojca, J.G. Pawllikowskiego rkps 12335 IV, Korespondencja M. Pawlikowskiego z lat 1893-1970, t. 76, listy Rozwadowskich

Centralne Państwowe Archiwum Historyczne Ukrainy we Lwowie:

zesp. 134, opis 2, sygn. 501, Inwentarz majątku Gwalberta Pawlikowskiego z 1836 r.

Lwowska Naukowa Biblioteka im. W. Stefanyka:

zesp. 76, Zbiór rękopisów i archiwum Pawlikowskich, cz. III:

sygn. 110, Wycinki prasowe z artykułami J. G. Pawlikowskiego 1898-1939

sygn. 200, Korespondencja J. G. Pawlikowskiego. Listy od rodziny 1919-1933

sygn. 201, Korespondencja J. G. Pawlikowskiego. Listy od rodziny

sygn. 203, Korespondencja J.G. Pawlikowskiego. Listy od różnych organizacji, towarzystw, wydawnictw i osób prywatnych 1931-1938

sygn. 206, Materiaty różne J. G. Pawlikowskiego1881-1937

sygn. 209, Korespondencja J. G. Pawlikowskiego. Listy od instytucji, organizacji i osób prywatnych $1934-1938$

sygn. 211, Materiały majątkowe Pawlikowskich (kontrakty, wyroki sadowe, rachunki) 1915-1935

sygn. 226, Wspomnienia i materialy M. Pawlikowskiego dotyczace wydarzeń lat 1922-1927

sygn. 227, Wspomnienia i materiaty M. Pawlikowskiego dotyczace lat 1929-1935

sygn. 229, Wspomnienia i materiały M. Pawlikowskiego dotyczace wydarzeń lat 1929-1935

sygn. 233, Korespondencja M. Pawlikowskiego. Listy od organizacji, towarzystw i osób prywatnych 1922--1939

sygn. 418, Pawlikowska Aniela. Listy do B. Obertyńskiej z 1929 r.

sygn. 419, Pawlikowska Aniela. Listy do B. Obertyńskiej z 1930 r.

Sąd Rejonowy w Przemyślu. Archiwum VI Wydziału Ksiąg Wieczystych:

Większe posiadłości ziemskie, t. 13 Buców lwh 385, t. 23 Starzawa lwh 735

Zakład Narodowy im. Ossolińskich we Wrocławiu. Oddzial Rękopisów:

sygn. 7948 II, Korespondencja Jana Emanuela Rozwadowskiego, t. 4-5

\section{Źródla drukowane:}

Dziennik urzędowy województwa lwowskiego z 1927 r., $\mathrm{nr} 3$.

Dziennik urzędowy województwa stanisławowskiego z 1927 r., nr 10.

Kalendarz Myśliwski na rok 1939, pod red. W. Garczyńskiego, Warszawa 1939.

Kronika Uniwersytetu Poznańskiego za rok szkolny 1927/1928, Poznań 1928.

Księga adresowa Polski (wraz z w. m. Gdańskiem) dla handlu, przemystu, rzemiost i rolnictwa, Warszawa 1930.

K. Pawlikowski, Z Medyki. Wspomnienia rodzinne, Kraków 2017.

Rolnik 1867-1937, Lwów 1938.

Rozporządzenie Prezydenta Rzeczypospolitej Polskiej z dnia 24 X 1934 r. o konwersji i uporzadkowaniu dlugów rolniczych, Dz. U. $1950 \mathrm{nr}$ 94, poz. 840, 841.

Sprawozdanie z działalności lwowskiej izby rolniczej na rok budżetowy 1936/37, Lwów 1938.

\section{Czasopisma:}

„Gazeta Rolnicza” 1938, nr 38 
„Myśl Polska”1941, nr z 15 XI 1941 r.

„Słowo Narodowe” 1937, nr 31 i 32

„Wiadomości Kościelne” 1932, nr 4

„Widnokrąg” 1984, nr 6

\section{Opracowania:}

S. Brzozowski, R. Skręt, Jan Gwalbert Pawlikowski, [w:] Polski Stownik Biograficzny, t. 25, Wrocław-Warszawa-Kraków-Gdańsk 1980.

T. Epsztein, S. Górzyński, Ziemianie polscy XX w. Słownik biograficzny, cz. 10, Warszawa 2013.

B. Jakubowski, Michat Pawlikowski jako ziemianin - właściciel klucza medyckiego w latach 19191939, „Rocznik Przemyski. Historia”, t. 54, 2018, z. 1(21), s. 103-130.

B. Jakubowski, Rozwadowscy w Nowostawach, „Czas Medycki” 2018, nr 1, s. 8-10.

K. Jasiewicz, Lista strat ziemiaństwa polskiego 1939-1956, Warszawa 1995.

Kto byt kim w Drugiej Rzeczypospolitej, red. J. M. Majchrowski, Warszawa 1994.

T. Misiak, W dorzeczu środkowego Sanu. Środowisko przyrodnicze. Przemiany na przestrzeni wieków i ochrona, Przemyśl 2005.

M. Mizorski, Gospodarstwo karpiowe: budowa karpia i zaktadanie stawów, Warszawa 1935.

M. Patelski, Generał broni Tadeusz Jordan Rozwadowski. Żotnierz i dyplomata, Warszawa 2002.

G. Rąkowski, Polska Egzotyczna, cz. II, Pruszków 2002.

E. Rozwadowski, Historia rodziny Jordan Rozwadowskich, Wrocław 2015.

P. Ruciński, Jan Emanuel Rozwadowski. Biografia polityka, działacza społecznego, uczonego (do 1914 r.), Łomianki 2020

R. Skręt, A. Szklarska-Lohmanowa, Michał Pawlikowski, [w:] Polski Stownik Biograficzny, t. 25, Wrocław 1980, s. 455-459.

J. Socha, Polski Zawodowy Zwiąek Rolników i Leśników z Wyższym Wykształceniem (1919-1939), „Acta Universitatis Lodzensis” 1990.

Szlaki znane i nieznane na obszarze działania Lokalnej Grupy Rybackiej ,, Starzawa”, Rzeszów 2013.

A. Zapałowski, Granica w ogniu. 35 „Przemyska” Komeda odcinka WOP w działaniach przeciw OUN i UPA w latach 1945-1948, Warszawa 2016.

\section{Strony internetowe:}

www.rozwadowski.org, tamże Pamiętnik Tadeusza, syna Wincentego Rozwadowskiego

www.starzawa.pl

www.dobroni.pl

www.archiwumkorporacyjne.pl/index.php/muzeum-korporacyjne/poznan/k-corona 

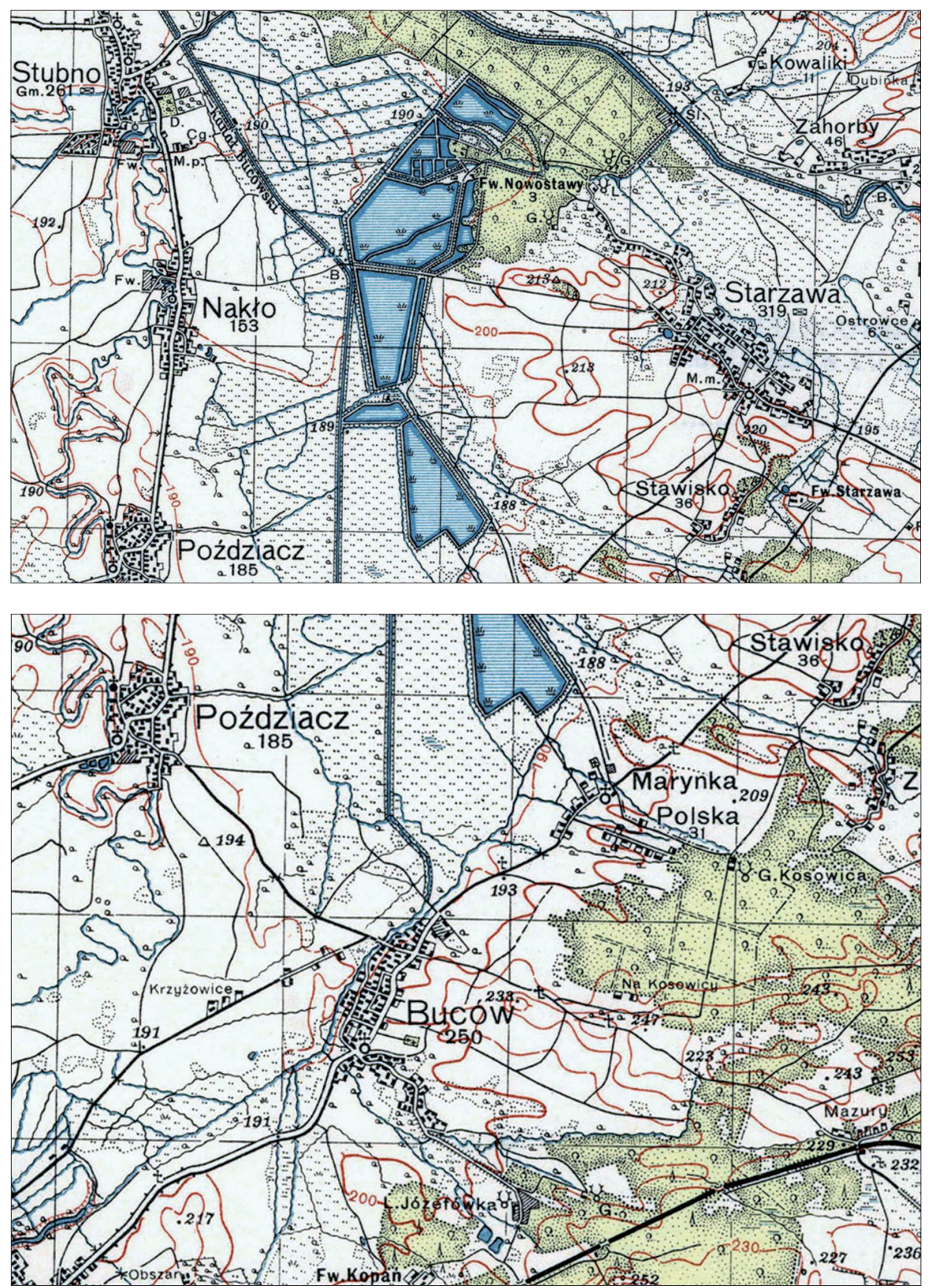

Fragmenty mapy z 1938 r. w skali 1:25000 z obszarem lasu „Kosowica” żródło:maps.mapywig.org/m/WIG_maps/series/100K_300dpi/P49_S36_MOSCISKA_1938 _300dpi_bcuj302574-289601.jpg 


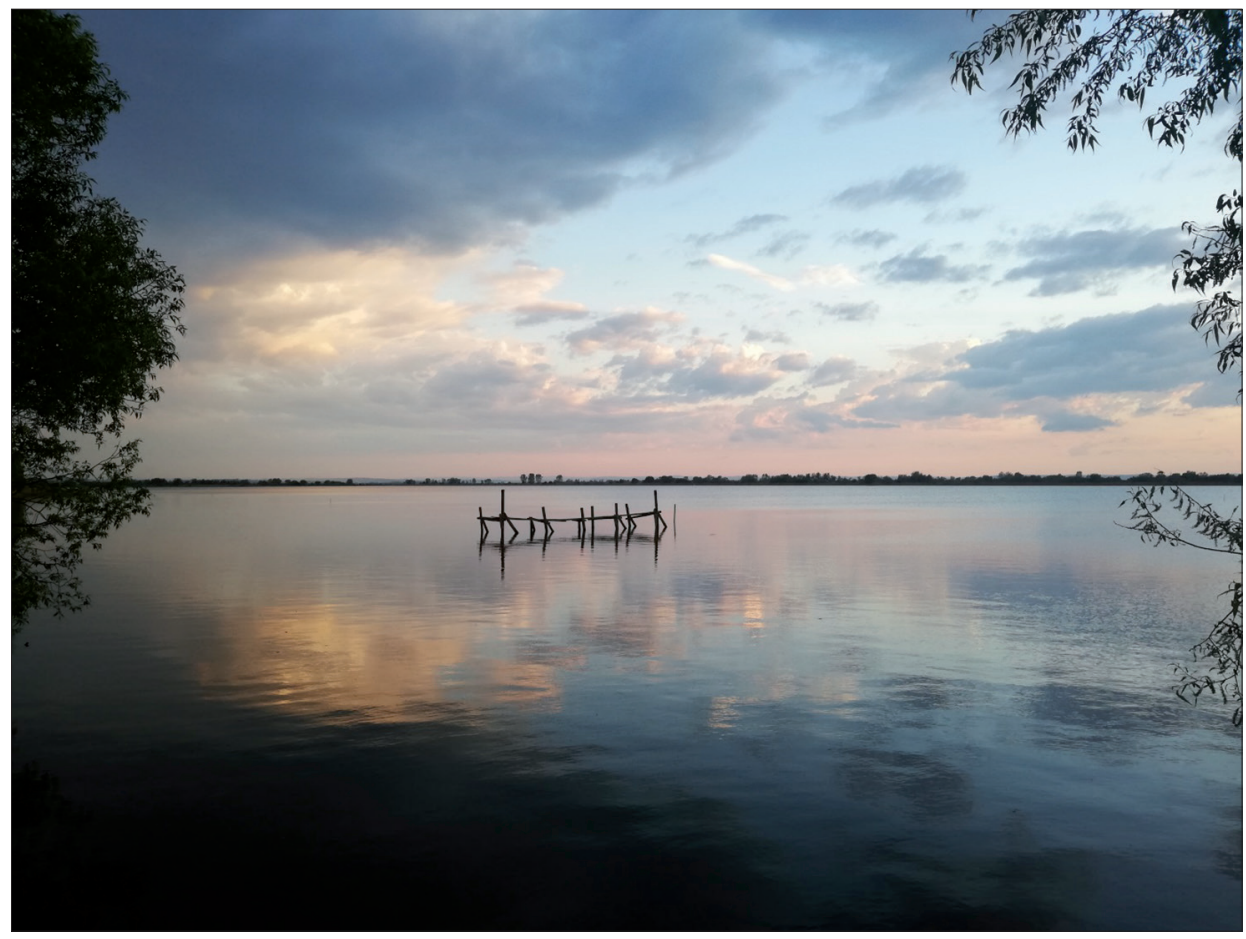

Stawy w Starzawie (w Nowostawach), fot. B. Jakubowski, 2019 r.

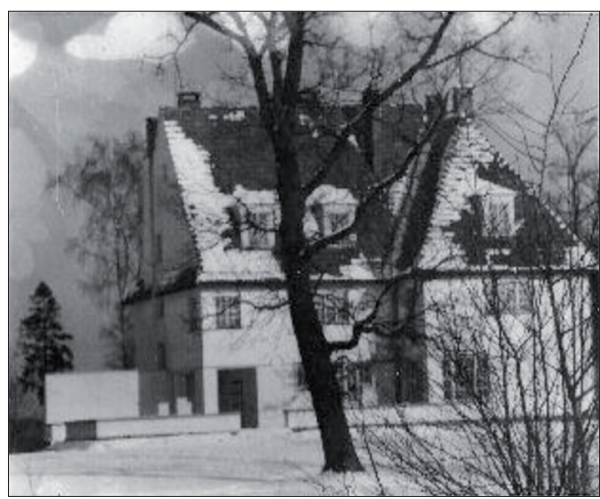

Wczoraj i dziś.

Dom Bartłomieja Rozwadowskiego w Nowostawach,

http://rozwadowski.org/v2.0.1.2/index. php/2015/07/21/w-nowostawach-1930-1939/

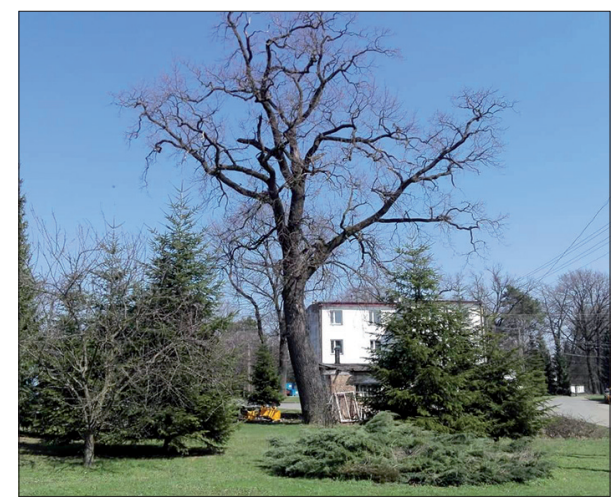

Budynek administracyjny postawiony na fundamentach domu zrujnowanego $\mathrm{w}$ czasie II wojny światowej, fot. B. Jakubowski, 2019 r. 


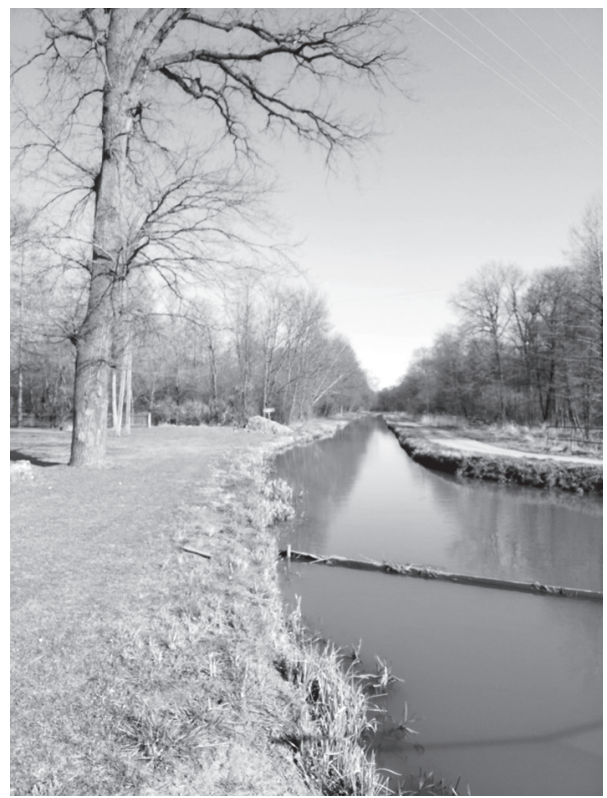

Nowostawy. Kanał doprowadzający wodę z Wiszni i potoku Krzywula, fot. B. Jakubowski, 2019 r.

Bartłomiej Rozwadowski z siostrą Izą przy kanale, źródło: http://rozwadowski.org/v2.0.1.2/ index.php/2015/07/21/

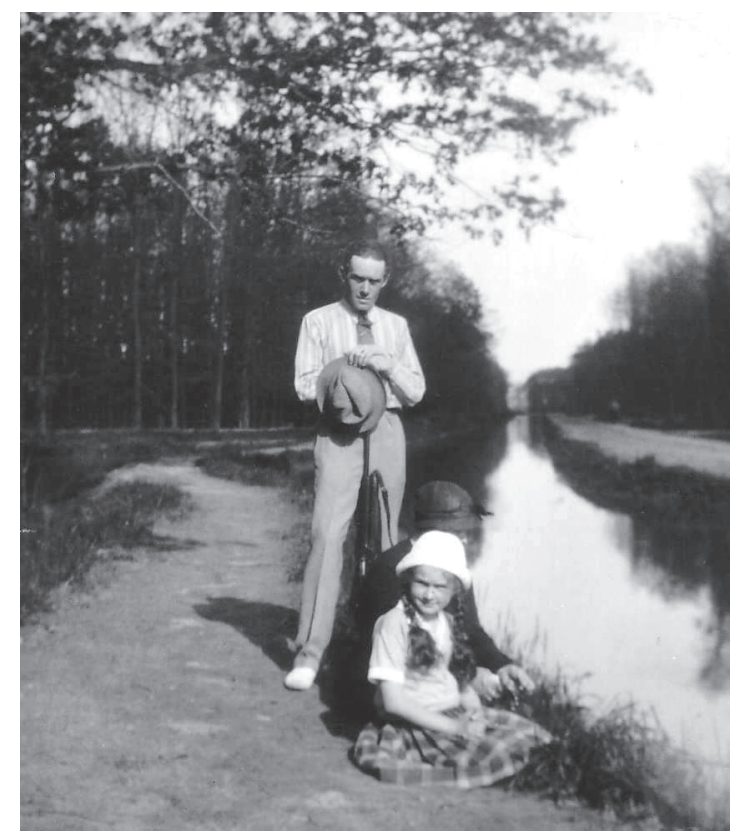
w-nowostawach-1930-1939/ 


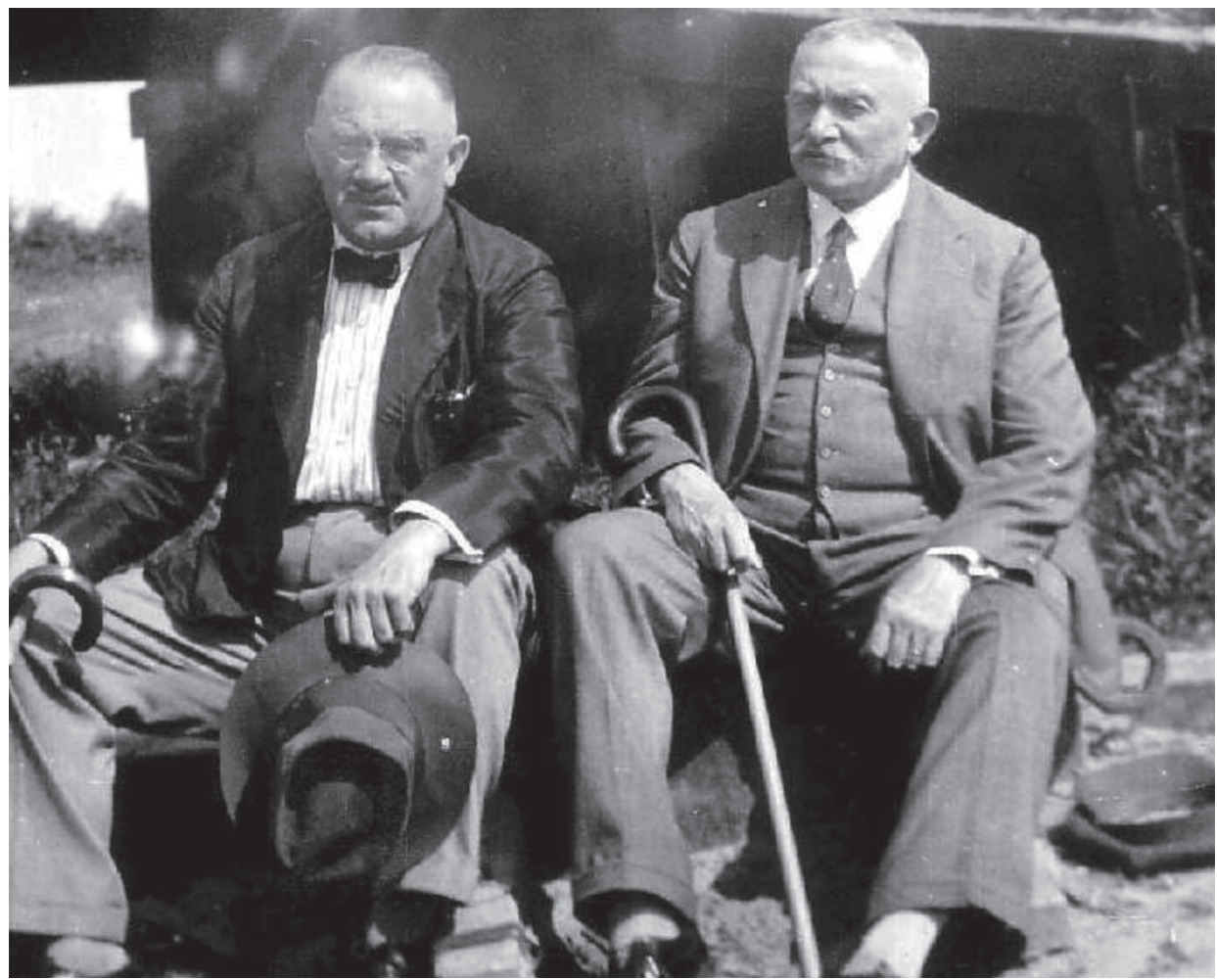

Bracia Wincenty i Jan Emanuel Rozwadowscy przy jazie na Wiszni w $1932 \mathrm{r}$.

fot. http://rozwadowski.org/v2.0.1.2/index.php/2015/07/21/w-nowostawach-1930-1939/, dostęp 12 III $2020 \mathrm{r}$.

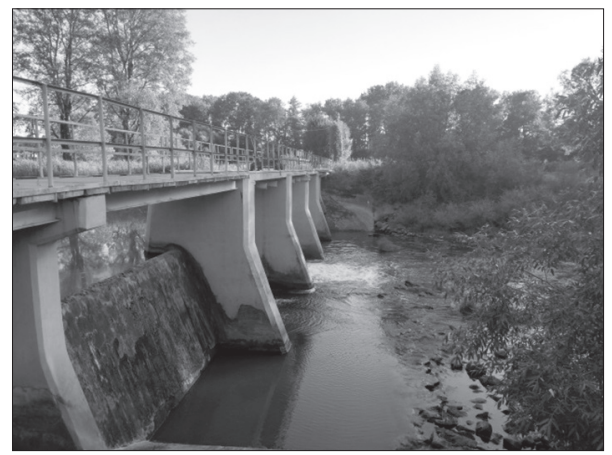

Jaz na rzece Wiszni, fot. B. Jakubowski, 2019 r.

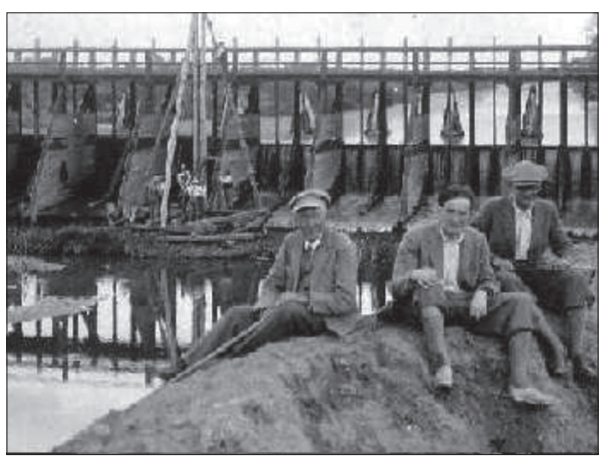

Budowa jazu na rzece Wiszni, 1932 r. źródło: http://rozwadowski.org/v2.0.1.2/index. php/2015/07/21/w-nowostawach-1930-1939/ 

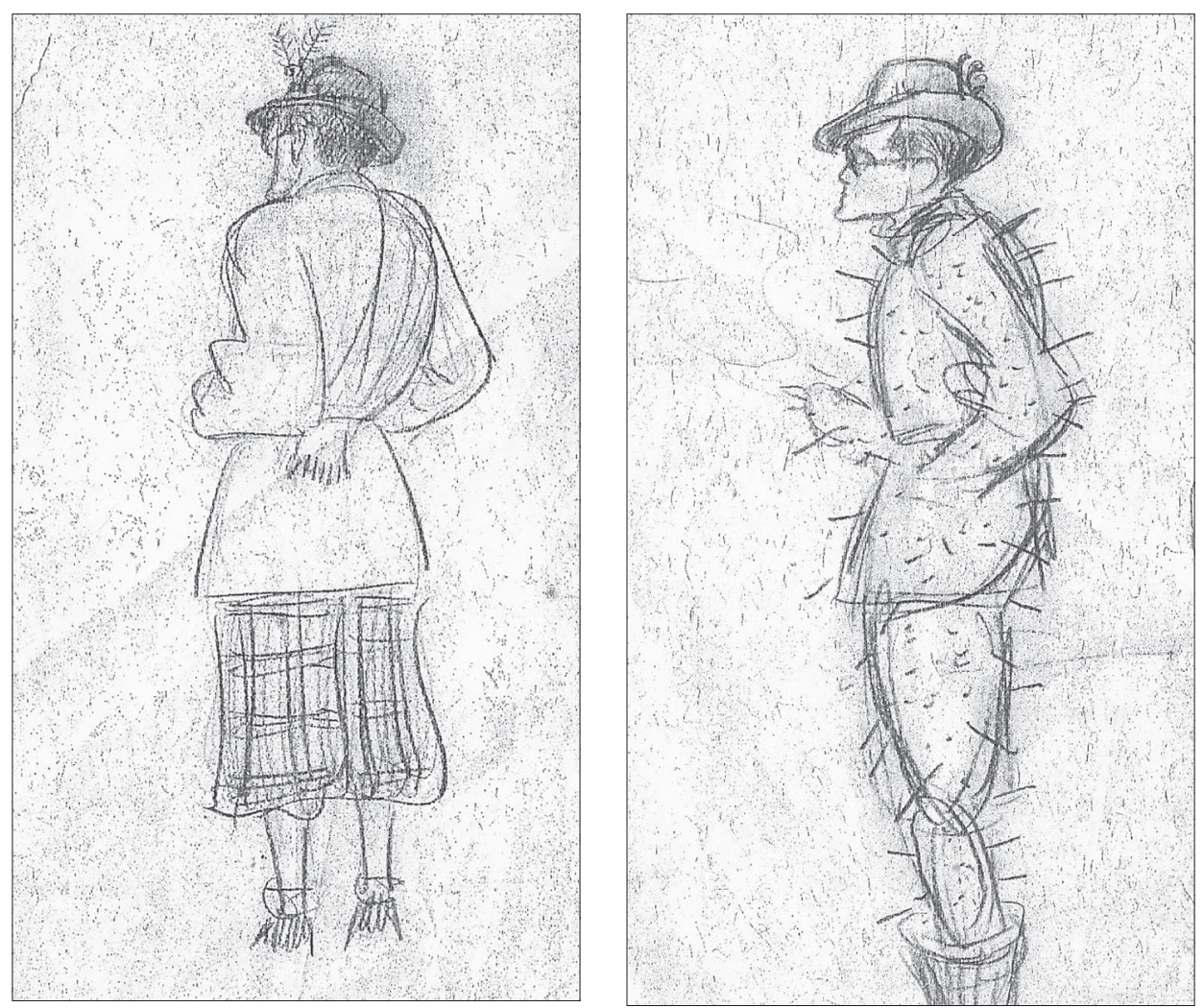

Bartłomiej Rozwadowski, karykatury Leli Pawlikowskiej. 1937-1938 r., fot. Ze zbiorów rodziny Pawlikowskich. 